\title{
Secondary organic aerosol formation from photooxidation of naphthalene and alkylnaphthalenes: implications for oxidation of intermediate volatility organic compounds (IVOCs)
}

\author{
A. W. H. Chan ${ }^{1}$, K. E. Kautzman ${ }^{1}$, P. S. Chhabra ${ }^{1}$, J. D. Surratt ${ }^{1}$, M. N. Chan ${ }^{2}$, J. D. Crounse ${ }^{1}$, A. Kürten ${ }^{2, *}$, \\ P. O. Wennberg ${ }^{2,3}$, R. C. Flagan ${ }^{1,2}$, and J. H. Seinfeld ${ }^{1,2}$ \\ ${ }^{1}$ Division of Chemistry and Chemical Engineering, California Institute of Technology, Pasadena, CA, USA \\ ${ }^{2}$ Division of Engineering and Applied Sciences, California Institute of Technology, Pasadena, CA, USA \\ ${ }^{3}$ Division of Geological and Planetary Sciences, California Institute of Technology, Pasadena, CA, USA \\ * current affiliation: Institute for Atmospheric and Environmental Sciences, Goethe-University Frankfurt am Main, \\ Frankfurt, Germany
}

Received: 27 November 2008 - Published in Atmos. Chem. Phys. Discuss.: 21 January 2009

Revised: 15 April 2009 - Accepted: 23 April 2009 - Published: 12 May 2009

\begin{abstract}
Current atmospheric models do not include secondary organic aerosol (SOA) production from gas-phase reactions of polycyclic aromatic hydrocarbons (PAHs). Recent studies have shown that primary emissions undergo oxidation in the gas phase, leading to SOA formation. This opens the possibility that low-volatility gas-phase precursors are a potentially large source of SOA. In this work, SOA formation from gas-phase photooxidation of naphthalene, 1-methylnaphthalene (1-MN), 2-methylnaphthalene (2$\mathrm{MN})$, and 1,2-dimethylnaphthalene (1,2-DMN) is studied in the Caltech dual $28-\mathrm{m}^{3}$ chambers. Under high- $\mathrm{NO}_{\mathrm{x}}$ conditions and aerosol mass loadings between 10 and $40 \mu \mathrm{g} \mathrm{m}^{-3}$, the SOA yields (mass of SOA per mass of hydrocarbon reacted) ranged from 0.19 to 0.30 for naphthalene, 0.19 to 0.39 for $1-\mathrm{MN}, 0.26$ to 0.45 for $2-\mathrm{MN}$, and constant at 0.31 for 1,2-DMN. Under low- $\mathrm{NO}_{\mathrm{x}}$ conditions, the SOA yields were measured to be $0.73,0.68$, and 0.58 , for naphthalene, 1 $\mathrm{MN}$, and 2-MN, respectively. The SOA was observed to be semivolatile under high- $\mathrm{NO}_{\mathrm{x}}$ conditions and essentially nonvolatile under low- $\mathrm{NO}_{\mathrm{x}}$ conditions, owing to the higher fraction of ring-retaining products formed under low- $\mathrm{NO}_{\mathrm{x}}$ conditions. When applying these measured yields to estimate SOA formation from primary emissions of diesel engines and wood burning, PAHs are estimated to yield 3-5 times more SOA than light aromatic compounds over photooxidation timescales of less than $12 \mathrm{~h}$. PAHs can also account for up to $54 \%$ of the total SOA from oxidation of diesel emissions, representing a potentially large source of urban SOA.
\end{abstract}

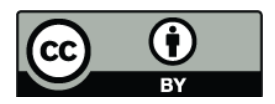

Correspondence to: J. H. Seinfeld (seinfeld@caltech.edu)

\section{Introduction}

Organic aerosol (OA) accounts for a large fraction of urban particulate matter (Seinfeld and Pankow, 2003; Zhang et al., 2007), and thus has important implications for health, climate and visibility. OA has traditionally been classified into two categories: primary organic aerosol (POA), which is directly emitted as particulate matter, and secondary organic aerosol (SOA), which is formed from atmospheric oxidation of volatile organic compounds (VOCs). POA has been assumed to be nonvolatile and chemically inert in atmospheric models, and are emitted primarily from anthropogenic sources, such as diesel and gasoline engines, wood burning and cooking operations (Schauer et al., 1996). On the other hand, SOA, formed from gas-phase oxidation of biogenic and anthropogenic volatile precursors, is an important source of OA both on global and local scales (Goldstein and Galbally, 2007; Docherty et al., 2008). Nonetheless, the amount of OA observed in urban sites is consistently higher than that for which volatile SOA precursors can account (de Gouw et al., 2005; Heald et al., 2005; Volkamer et al., 2006).

This POA/SOA classification has recently been called into question; during laboratory chamber photooxidation of diesel and biomass burning emissions, volatile SOA precursors, which consist primarily of light aromatic compounds such as benzene, toluene and xylene, can account for only a small fraction of the SOA produced (Robinson et al., 2007; Grieshop et al., 2009a,b). Robinson et al. (2007) proposed that gas-phase reactions of low-volatility compounds likely contribute to a large fraction of the SOA formed, as oxidation of these low-volatility organic vapors produces aerosol

Published by Copernicus Publications on behalf of the European Geosciences Union. 


Compound
1-methylnaphthalene
(1-MN)
$\begin{gathered}\text { 2-methylnaphthalene } \\ \text { (2-MN) }\end{gathered}$
$\begin{gathered}\text { 1,2- } \\ \text { dimethylnaphthalene } \\ (1,2-\mathrm{DMN})\end{gathered}$

Fig. 1. Structure of PAHs studied and $\mathrm{OH}$ rate constants (Phousongphouang and Arey, 2002).

that closely resembles OA observed in field measurements (Weitkamp et al., 2007; Sage et al., 2008; Grieshop et al., 2009a). While some of these compounds, including long chain $n$-alkanes, polycyclic aromatic hydrocarbons (PAHs), and large olefins, exist exclusively in the gas phase, they have lower volatilities than traditional SOA precursors and are typically ignored in current atmospheric models. These compounds, which have saturation concentrations between $10^{3}$ and $10^{6} \mu \mathrm{g} \mathrm{m}^{-3}$, are termed intermediate volatility organic compounds (IVOCs) (Donahue et al., 2009).

PAHs have been identified as a major component in emissions from diesel engines and wood burning sources (Schauer et al., 1999a, 2001). While PAHs with fewer than 4 aromatic rings exist primarily in the gaseous phase, photooxidation of these compounds has been shown to yield high molecular weight (MW) oxygenated compounds (Sasaki et al., 1997; Bunce et al., 1997; Wang et al., 2007), which can partition into the particle phase and lead to significant SOA formation (Mihele et al., 2002). Moreover, nitronaphthalene, an oxidation product of naphthalene, and other nitro PAHs have been observed in urban particulate matter (Arey et al., 1989). The oxidation of PAHs in the gas phase will likely have significant impacts on both the quantity and the properties of SOA formed in urban atmospheres. In this study, we present results on SOA formation from gas-phase photooxidation of naphthalene, 1-methylnaphthalene (1-MN), 2-methylnaphthalene (2-MN) and 1,2-dimethylnaphthalene (1,2-DMN). The SOA yields, the mass of SOA formed per mass of PAH reacted, are then used to evaluate the importance of PAHs as effective SOA precursors.

\section{Experimental}

Experiments were carried out in the Caltech dual $28-\mathrm{m}^{3}$ Teflon chambers. Details of the facilities have been described previously (Cocker et al., 2001; Keywood et al., 2004). Be- fore each experiment, the chambers were flushed with dried purified air for $>24 \mathrm{~h}$, until the particle number concentration was $<100 \mathrm{~cm}^{-3}$ and the volume concentration was $<0.1 \mu \mathrm{m}^{3} \mathrm{~cm}^{-3}$.

In most experiments, an inorganic seed aerosol was used to provide a surface for condensation of semivolatile oxidation products. Seed aerosol was generated by atomization of a $0.015 \mathrm{M}$ aqueous ammonium sulfate solution. The aerosol size distribution, number and volume concentrations were measured with a differential mobility analyzer (DMA, TSI, 3081) coupled with a condensation nuclei counter (TSI, CNC-3760). The volume concentration was corrected for particle wall loss by applying size-dependent first-order loss coefficients, obtained in a separate seed-only experiment (Keywood et al., 2004).

After atomization of inorganic seed, the parent hydrocarbon was then injected into the chamber; the injection method varied depending on its phase under room temperature conditions. For naphthalene and 2-MN, the hydrocarbon was introduced into the chamber by flowing purified air through an FEP tube packed with the solid PAH at $1 \mathrm{~L} \mathrm{~min}^{-1}$. For 1$\mathrm{MN}$ and 1,2-DMN, a known volume of the liquid PAH was injected into a heated glass bulb, and the vapor was carried into the chamber with $5 \mathrm{~L} \mathrm{~min}^{-1}$ of purified air. The parent hydrocarbons studied and their stated purities are as follows: naphthalene (Sigma-Aldrich, 99\%), 1-methylnaphthalene (Fluka, $\geq 97 \%$ ), 2-methylnaphthalene (Fluka, $\geq 95 \%$ ) and 1,2-dimethylnaphthalene (Aldrich, 95\%). The hydrocarbon was measured using a gas chromatograph with flame ionization detector (GC/FID, Agilent $6890 \mathrm{~N}$ ), equipped with an HP5 $15 \mathrm{~m} \times 0.53 \mathrm{~mm}$ ID column $\times 1 \mu \mathrm{m}$ thickness column. The GC response was calibrated by dissolving a known mass of the parent PAH in dichloromethane, and vaporizing a small volume of that solution into a $38 \mathrm{~L}$ Teflon chamber.

For high- $\mathrm{NO}_{\mathrm{x}}$ experiments (initial $[\mathrm{NO}]>300 \mathrm{ppb}$ ), nitrous acid (HONO) was used as an $\mathrm{OH}$ precursor. Nitrous acid was prepared by adding $10 \mathrm{~mL}$ of $1 \mathrm{wt} \%$ aqueous $\mathrm{NaNO}_{2}$ dropwise into $20 \mathrm{~mL}$ of $10 \mathrm{wt} \%$ sulfuric acid in a glass bulb. A stream of purified air was then passed through the bulb, sending HONO into the chamber. This process also forms $\mathrm{NO}$ and $\mathrm{NO}_{2}$ as side products. The injection of $\mathrm{HONO}$ was stopped when $\left[\mathrm{NO}_{2}\right]$ reached about $80 \mathrm{ppb}$ in the chamber. Additional $\mathrm{NO}$ was added until total [NO] was about $400 \mathrm{ppb}$. $\mathrm{NO}_{2}$ was monitored by a gas chromatograph with luminol detector (University of California, Riverside, CA), in which $\mathrm{NO}_{2}$ and PAN were separated by gas chromatograph and detected by chemiluminescence of reaction with luminol (Burkhardt et al., 1988). Reaction of HONO with luminol is unlikely, and thus would not interfere with the $\mathrm{NO}_{2}$ signal. A commercial chemiluminescence $\mathrm{NO} / \mathrm{NO}_{\mathrm{x}}$ analyzer (Horiba, APNA 360) was used to monitor $\mathrm{NO}$ and total $\mathrm{NO}_{y}$. For low$\mathrm{NO}_{\mathrm{x}}$ experiments, hydrogen peroxide $\left(\mathrm{H}_{2} \mathrm{O}_{2}\right)$ was used as an $\mathrm{OH}$ precursor. Prior to atomization of the ammonium sulfate seed, $\mathrm{H}_{2} \mathrm{O}_{2}$ was introduced by bubbling purified air through a $50 \%$ aqueous $\mathrm{H}_{2} \mathrm{O}_{2}$ solution for $2.5 \mathrm{~h}$ at $5 \mathrm{~L} \mathrm{~min}^{-1}$. 
Table 1. Experimental conditions and results.

\begin{tabular}{|c|c|c|c|c|c|c|c|c|}
\hline Date (2008) & Compound & {$[H C]_{0}, \mathrm{ppb}$} & {$[\mathrm{NO}]_{0}, \mathrm{ppb}$} & {$\left[\mathrm{NO}_{2}\right]_{0}, \mathrm{ppb}$} & $V_{0}{ }^{\mathrm{a}}, \mu \mathrm{m}^{3} \mathrm{~cm}^{-3}$ & $\Delta H C, \mu \mathrm{g} \mathrm{m}^{-3}$ & $\Delta M_{o}, \mu \mathrm{g} \mathrm{m}^{-3}$ & Yield \\
\hline $6 / 12$ & naphthalene & 7.5 & $\mathrm{~b}$ & $\mathrm{c}$ & 12.9 & $39.5 \pm 2.5$ & $29.0 \pm 2.6$ & $0.73 \pm 0.11$ \\
\hline $6 / 14$ & naphthalene & 4.4 & $\mathrm{~b}$ & $\mathrm{c}$ & 14.2 & $22.8 \pm 2.1$ & $17.0 \pm 1.7$ & $0.74 \pm 0.15$ \\
\hline $6 / 17$ & naphthalene & 6.0 & $\mathrm{~b}$ & $\mathrm{c}$ & 13.9 & $31.2 \pm 2.1$ & $22.9 \pm 2.2$ & $0.73 \pm 0.12$ \\
\hline $6 / 19$ & naphthalene & 2.7 & $\mathrm{~b}$ & $\mathrm{c}$ & 14.5 & $14.4 \pm 2.0$ & $10.2 \pm 1.5$ & $0.71 \pm 0.21$ \\
\hline $6 / 13$ & naphthalene & 12.1 & 411 & 83 & 14.5 & $58.6 \pm 2.0$ & $10.9 \pm 1.5$ & $0.19 \pm 0.03$ \\
\hline $6 / 16$ & naphthalene & 21.2 & 304 & 73 & 13.6 & $92.7 \pm 2.1$ & $27.7 \pm 3.0$ & $0.30 \pm 0.04$ \\
\hline $6 / 18$ & naphthalene & 9.5 & 351 & 73 & 15.2 & $39.6 \pm 2.0$ & $8.0 \pm 1.2$ & $0.20 \pm 0.04$ \\
\hline \multirow[t]{2}{*}{$6 / 20$} & naphthalene & 17.0 & 411 & 66 & 15.4 & $65.0 \pm 1.6$ & $13.6 \pm 1.7$ & $0.21 \pm 0.03$ \\
\hline & & & & & & $83.9 \pm 2.1^{\mathrm{f}}$ & $22.8 \pm 2.2^{\mathrm{f}}$ & $0.27 \pm 0.03^{f}$ \\
\hline $7 / 16$ & 2-MN & 7.5 & $\mathrm{~b}$ & $\mathrm{c}$ & 13.2 & $58.6 \pm 3.4$ & $35.0 \pm 3.1$ & $0.60 \pm 0.09$ \\
\hline $7 / 22$ & 2-MN & 4.4 & $\mathrm{~b}$ & $\mathrm{c}$ & 14.6 & $31.5 \pm 3.0$ & $18.6 \pm 1.8$ & $0.59 \pm 0.11$ \\
\hline $7 / 24$ & 2-MN & 6.0 & $\mathrm{~b}$ & $\mathrm{c}$ & 12.9 & $22.5 \pm 3.3$ & $13.1 \pm 1.5$ & $0.58 \pm 0.15$ \\
\hline $7 / 27$ & 2-MN & 2.7 & $\mathrm{~b}$ & $\mathrm{c}$ & 13.3 & $43.3 \pm 3.0$ & $24.6 \pm 2.1$ & $0.57 \pm 0.09$ \\
\hline $7 / 21$ & 2-MN & 21.2 & 398 & 52 & 14.1 & $28.0 \pm 3.4$ & $7.4 \pm 0.9$ & $0.26 \pm 0.06$ \\
\hline $7 / 23$ & 2-MN & 9.5 & 376 & 51 & 14.2 & $47.3 \pm 3.5$ & $18.8 \pm 1.9$ & $0.40 \pm 0.07$ \\
\hline $7 / 25$ & 2-MN & 17.0 & $\mathrm{~d}$ & 55 & 12.9 & $70.7 \pm 3.4$ & $31.6 \pm 2.6$ & $0.45 \pm 0.06$ \\
\hline $7 / 29$ & 2-MN & 7.5 & d & 61 & 13.4 & $60.0 \pm 3.6$ & $24.3 \pm 2.2$ & $0.40 \pm 0.06$ \\
\hline $8 / 2$ & $1-\mathrm{MN}$ & 7.3 & $\mathrm{~b}$ & $\mathrm{c}$ & 11.4 & $42.9 \pm 3.9$ & $30.5 \pm 2.5$ & $0.71 \pm 0.12$ \\
\hline $8 / 5$ & $1-\mathrm{MN}$ & 9.9 & $\mathrm{~b}$ & $\mathrm{c}$ & 13.1 & $57.4 \pm 3.4$ & $37.6 \pm 3.0$ & $0.66 \pm 0.09$ \\
\hline $8 / 8$ & $1-\mathrm{MN}$ & 2.8 & $\mathrm{~b}$ & $\mathrm{c}$ & 13.8 & $15.7 \pm 3.4$ & $10.7 \pm 1.1$ & $0.68 \pm 0.22$ \\
\hline $8 / 17$ & $1-\mathrm{MN}$ & 5.9 & $\mathrm{~b}$ & $\mathrm{c}$ & 14.0 & $35.2 \pm 3.6$ & $24.0 \pm 2.4$ & $0.68 \pm 0.14$ \\
\hline $8 / 4$ & $1-\mathrm{MN}$ & 10.5 & d & 77 & 13.6 & $51.8 \pm 3.0$ & $16.5 \pm 1.6$ & $0.32 \pm 0.05$ \\
\hline $8 / 7$ & $1-\mathrm{MN}$ & 5.3 & 333 & 55 & 13.5 & $30.1 \pm 3.4$ & $5.6 \pm 0.9$ & $0.19 \pm 0.05$ \\
\hline $8 / 9$ & $1-\mathrm{MN}$ & 14.6 & 388 & 62 & 14.7 & $79.6 \pm 3.6$ & $30.9 \pm 2.6$ & $0.39 \pm 0.05$ \\
\hline $8 / 11$ & $1-\mathrm{MN}$ & 16.8 & 401 & 56 & 14.6 & $91.0 \pm 3.6$ & $34.9 \pm 3.1$ & $0.38 \pm 0.05$ \\
\hline $9 / 10$ & $1,2-\mathrm{DMN}$ & 34.8 & 392 & 51 & 14.7 & $215.7 \pm 6.8$ & $66.9 \pm 5.3$ & $0.31 \pm 0.03$ \\
\hline $9 / 12$ & 1,2-DMN & 12.3 & 397 & 60 & 14.9 & $76.8 \pm 4.4$ & $23.1 \pm 2.3$ & $0.30 \pm 0.05$ \\
\hline $9 / 14$ & $1,2-\mathrm{DMN}$ & 4.1 & 377 & 55 & 14.2 & $25.4 \pm 3.3$ & $7.8 \pm 1.4$ & $0.31 \pm 0.10$ \\
\hline
\end{tabular}

${ }^{\mathrm{a}} V_{o}$ : volume concentration of ammonium sulfate seed; ${ }^{\mathrm{b}}$ below detection limit of $2 \mathrm{ppb} ;{ }^{\mathrm{c}} \mathrm{NO}_{2}$ concentration was not measured by gaschromatograph in these experiments due to $\mathrm{H}_{2} \mathrm{O}_{2}$ interference with $\mathrm{NO}_{2}$ signal, but inferred to be $<2 \mathrm{ppb}$ from $\mathrm{NO} / \mathrm{NO}_{\mathrm{x}}$ analyzer; ${ }^{\mathrm{d}} \mathrm{NO}$ concentration not measured, but expected to be similar to that of other high- $\mathrm{NO}_{\mathrm{x}}$ experiments; ${ }^{\mathrm{e}} \mathrm{Nucleation}$ experiments not shown; with the exception of seed concentration, conditions were similar to those of experiments shown here; ${ }^{\mathrm{f}} \mathrm{After}$ second addition of HONO

After allowing for all concentrations to stabilize, irradiation was initiated. The temperature of the chamber reached $299 \mathrm{~K}$, and the $\mathrm{RH}$ of the experiments was between 5 and $8 \%$. Figure 1 lists the structures of the parent hydrocarbons and their $\mathrm{OH}$ reaction rate constants $\left(k_{\mathrm{OH}}\right)$. The experimental conditions prior to beginning of irradiation and the results are summarized in Table 1. Photooxidation of 1,2-DMN under low- $\mathrm{NO}_{\mathrm{x}}$ conditions was not studied. Owing to its fast $\mathrm{OH}$ reaction rate, 1,2-DMN will likely be consumed near its ambient sources, where $\mathrm{NO}_{\mathrm{x}}$ concentrations are likely to be high.

A proton transfer reaction mass spectrometer (PTR-MS), custom modified Varian 1200 system, was used to monitor the concentrations of various gas-phase species. Details of the instrument are given in $\mathrm{Ng}$ et al. (2007a). In brief, positively charged water clusters, $\left(\mathrm{H}_{2} \mathrm{O}\right)_{n} \cdot \mathrm{H}^{+}$, react via proton transfer with the analyte, $A$, to form the positively charged ion, $A \cdot\left(\mathrm{H}_{2} \mathrm{O}\right)_{x} \cdot \mathrm{H}^{+}$, where $0 \leq x \leq n$. Species were predom- inantly observed at $m / z=M+1$, where $M$ is the molecular mass of the species. Hydrates, $A \cdot\left(\mathrm{H}_{2} \mathrm{O}\right) \cdot \mathrm{H}^{+}$, were also observed for 2-formylcinnamaldehyde and phthalic anhydride.

Real-time aerosol mass spectra were obtained using an Aerodyne high-resolution time-of-flight aerosol mass spectrometer (HR-TOF-AMS) (DeCarlo et al., 2006). These data were also used to calculate the density of SOA by comparing the particle mass distribution obtained using the particle time-of-flight mode and the volume distribution obtained by the DMA in nucleation (seed-free) experiments (Bahreini et al., 2005).

\section{Results}

\subsection{Concentrations of $\mathrm{NO}$ and $\mathrm{NO}_{2}$}

Figure 2 shows mixing ratios of $\mathrm{NO}$ and $\mathrm{NO}_{2}$ in a typical high- $\mathrm{NO}_{\mathrm{x}}$ experiment (6/16). Following the onset of 

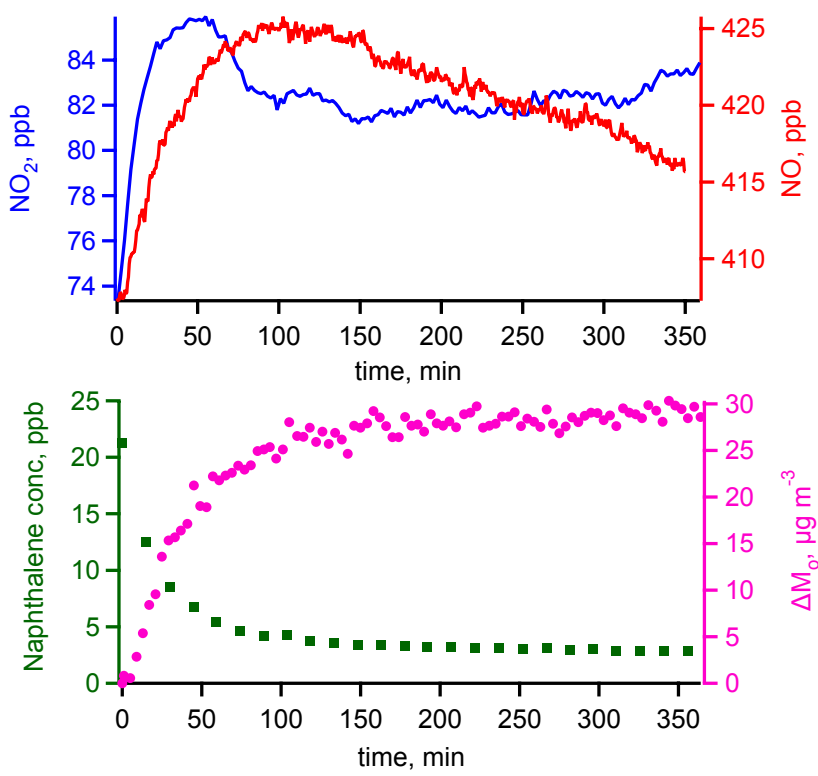

Fig. 2. Reaction profile during a typical high- $\mathrm{NO}_{\mathrm{x}}$ experiment. The mass concentration of SOA has been corrected for particle wall loss.

Table 2. Effective SOA densities $\left(\mathrm{g} \mathrm{cm}^{-3}\right)$, obtained in nucleation experiments.

\begin{tabular}{ccc}
\hline & high-NO & low- $\mathrm{NO}_{\mathrm{x}}$ \\
\hline naphthalene & 1.48 & 1.55 \\
1-MN & 1.4 & 1.43 \\
2-MN & 1.35 & 1.3 \\
1,2-DMN & $\mathrm{a}$ & - \\
\hline
\end{tabular}

${ }^{\mathrm{a}}$ Not measured; assumed to be 1.4

irradiation, photolysis of $\mathrm{HONO}$ produces $\mathrm{OH}$ and $\mathrm{NO}$. The level of NO remained above $400 \mathrm{ppb}$, and no ozone formation was observed. Also, owing to the high NO levels, the reaction of $\mathrm{RO}_{2}$ radicals (produced in the $\mathrm{OH}$ oxidation) with $\mathrm{NO}$ likely dominated over that with $\mathrm{HO}_{2}$ or $\mathrm{RO}_{2}$ radicals.

Following the addition of $\mathrm{OH}$ to the aromatic ring, the aromatic-cyclohexadienyl radical can react with $\mathrm{NO}_{2}$ to form nitronaphthalenes or with $\mathrm{O}_{2}$ to form peroxy radicals (Atkinson et al., 1987; Nishino et al., 2008). The relative rates of these reactions depend on the concentration of $\mathrm{NO}_{2}$, which remained between 50 and $100 \mathrm{ppb}$ in all high- $\mathrm{NO}_{\mathrm{x}}$ experiments, as measured by the $\mathrm{GC} / \mathrm{NO}_{2}-\mathrm{PAN}$ analyzer. This level is typical of urban polluted conditions, and suggests that the branching ratios in these experiments are relevant for regions where PAHs are commonly emitted. Nishino et al. (2008) reports that the reaction rates of $\mathrm{OH}$-naphthalene adduct with $\mathrm{NO}_{2}$ and $\mathrm{O}_{2}$ are equal at $\left[\mathrm{NO}_{2}\right] \approx 60 \mathrm{ppb}$.

In the low- $\mathrm{NO}_{\mathrm{x}}$ experiments, $\mathrm{NO}$ and $\mathrm{NO}_{2}$ concentrations were below limits of detection ( $2 \mathrm{ppb})$. Ozone was formed at a rate of $2.5 \mathrm{ppbh}^{-1}$, likely due to reactions of $\mathrm{NO}_{\mathrm{y}}$ contaminants on the chamber walls. Based on the low reaction rate constants of aromatic compounds with $\mathrm{O}_{3}$, such reactions are not expected to be significant.

\subsection{Gas-Phase Composition}

The gas-phase photooxidation products of naphthalene have been identified in previous studies (Sasaki et al., 1997; Bunce et al., 1997; Wang et al., 2007; Nishino et al., 2009). Oxidation products identified in the current work by PTR-MS are consistent with those previously observed. Gas-phase mass spectra measured by PTR-MS during photooxidation of naphthalene under high- and low- $\mathrm{NO}_{\mathrm{x}}$ and the proposed structures for the ions observed are shown in Figs. 3 and 4, respectively.

\subsection{Aerosol formation}

Figure 2 shows the mixing ratio of naphthalene and the mass concentration of SOA formed in the experiment on 6/16. Under high- $\mathrm{NO}_{\mathrm{x}}$ conditions, owing to the efficient photolysis of $\mathrm{HONO}$, the average $\mathrm{OH}$ concentrations are on the order of $1.5 \times 10^{7}$ molec $\mathrm{cm}^{-3}$, as estimated from the parent hydrocarbon decay. After 100 min of irradiation, HONO was depleted and, for naphthalene, further SOA formation was insignificant. Due to the relatively slow reaction rate of naphthalene with $\mathrm{OH}$, only $85 \%$ of the initial naphthalene had been consumed before HONO was depleted. In one high- $\mathrm{NO}_{\mathrm{x}} \mathrm{ex}-$ periment with an initial naphthalene concentration of $17 \mathrm{ppb}$ (6/20), $4 \mathrm{ppb}$ remained after HONO was depleted. More HONO was added to consume the remaining naphthalene, resulting in further aerosol formation. For the other PAHs, less than $7 \%$ of the initial concentration remained unreacted. Under low- $\mathrm{NO}_{\mathrm{x}}$, a continuous supply of $\mathrm{OH}$ radicals was generated from the slow photolysis of $\mathrm{H}_{2} \mathrm{O}_{2}$, and the parent hydrocarbon concentration was below detection limits at the end of the experiment. The average $\mathrm{OH}$ concentrations for these experiments were on the order of $3 \times 10^{6} \mathrm{molec} \mathrm{cm}^{-3}$.

The SOA mass concentrations and yields for all experiments are summarized in Table 1. To calculate the mass concentration of SOA, the volume concentration measured by the DMA was multiplied by its respective SOA density, obtained in separate nucleation experiments. Values for the densities are summarized in Table 2 .

\section{Aerosol formation}

\subsection{Relative rates of oxidation steps}

Figure 5 shows the time-dependent growth curves, mass concentration of SOA formed, $\Delta M_{o}$, as a function of mass of hydrocarbon reacted, $\triangle H C$, for all experiments. For naphthalene under both high- and low- $\mathrm{NO}_{\mathrm{x}}$ conditions, the growth curves overlap; the lack of a vertical portion indicates 

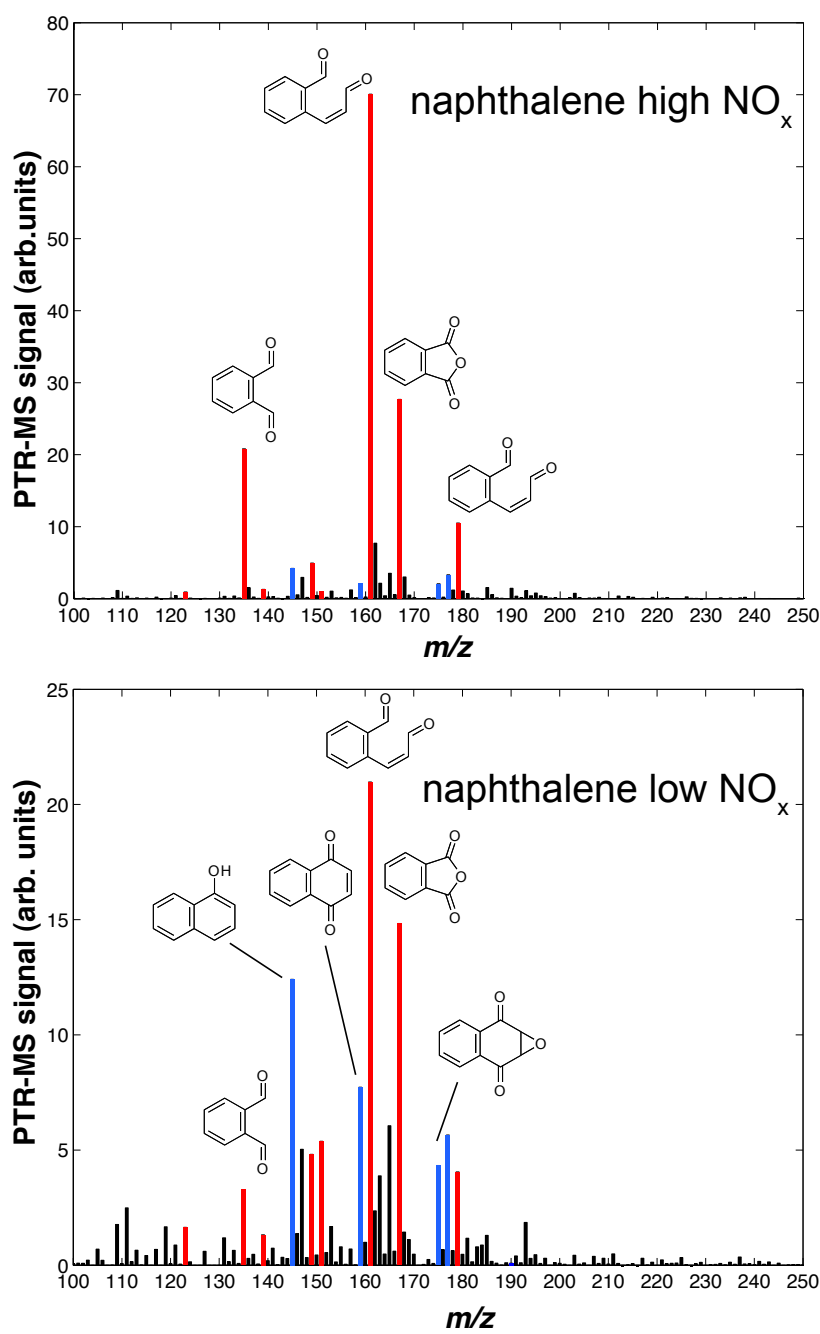

Fig. 3. PTR-MS spectra under high- and low- $\mathrm{NO}_{\mathrm{x}}$ conditions. The fractions of naphthalene reacted are 0.66 and 0.67 , respectively. The red peaks indicate ions associated with ring-opening products, and the blue peaks indicate those associated with ring-retaining products. The proposed structures for these ion peaks are given in Fig. 4.

that SOA formation likely results either from first-generation products, or from higher generation products that are formed rapidly ( $\mathrm{Ng}$ et al., 2006; Chan et al., 2007). In the high$\mathrm{NO}_{\mathrm{x}}$ experiment in which a second HONO addition was conducted (6/20), SOA growth from the second injection of HONO was identical to that in another experiment with a higher initial hydrocarbon concentration. These observations suggest that the first oxidation step is rate-limiting, and the trend in aerosol growth for naphthalene can be represented by a single growth curve.

On the contrary, the growth curves for methylsubstituted naphthalenes display a vertical portion (hook) at higher $\triangle H C$. In photooxidation of 1-MN and 2-MN under both high- and low- $\mathrm{NO}_{\mathrm{x}}$, and that of 1,2-DMN under high- $\mathrm{NO}_{\mathrm{x}}$,

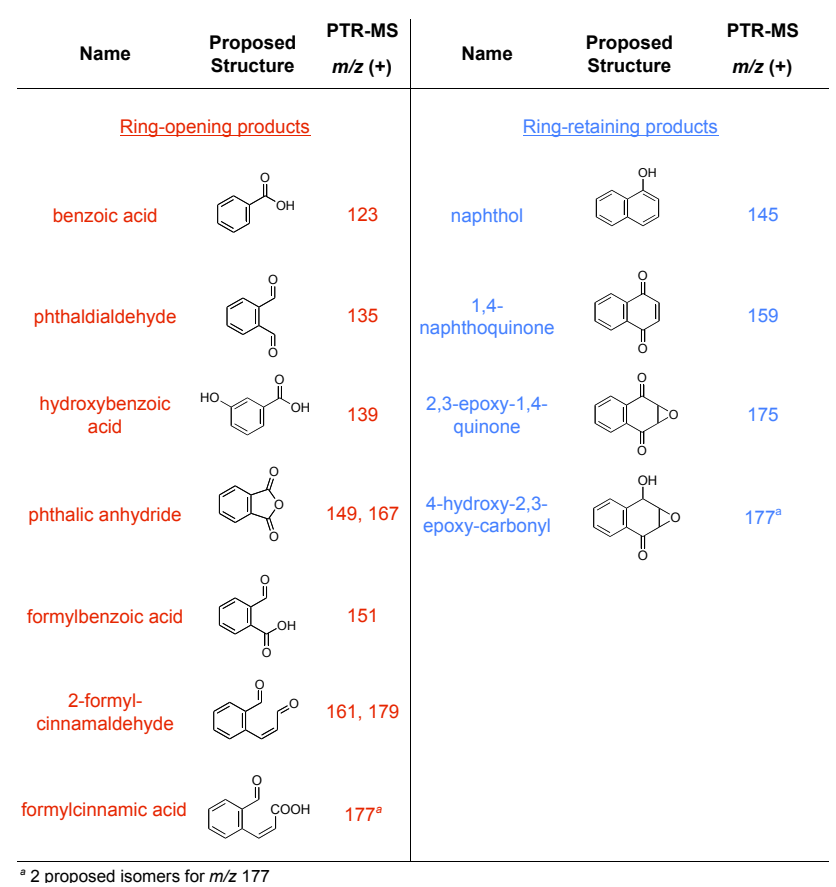

Fig. 4. Proposed compounds and structures for ion peaks observed by PTR-MS. The ring-opening gas-phase products are marked red and the gas-phase ring-retaining products are marked blue, to correspond to Fig. 3.

delayed aerosol growth was observed after a large fraction $(>90 \%)$ of the parent PAH had been consumed. In addition, the degree of divergence for different growth curves is greater for 1,2-DMN, which has a larger number of methyl groups. While one cannot rule out the possibility of forming low-volatility compounds from photolysis of aromatic carbonyls and hydroperoxides, the delay in aerosol growth relative to the first oxidation step can also be explained by the relative rates of reaction. Figure 6 shows the oxidation mechanisms for naphthalene and 1-methylnaphthalene that lead to the major dicarbonyl product. As the aromatic ring becomes more substituted, the reaction rate of $\mathrm{OH}$ with the parent PAH increases (Phousongphouang and Arey, 2002). Further reaction of the dicarbonyl can occur by $\mathrm{OH}$ addition to the olefinic double bond, or by abstraction of aldehydic hydrogen atom. $\mathrm{OH}$ addition to the olefinic double bond is likely unaffected by substitution of methyl groups, and $\mathrm{H}$-abstraction is slower for the methyl-substituted dicarbonyl product because of one fewer aldehyde group. As a result, the relative rate of the second step is slower for methylsubstituted naphthalenes, resulting in divergence of growth curves and delayed SOA growth relative to the oxidation of the parent PAH. Since further oxidation of gas-phase intermediates will likely lead to even lower volatility products and more SOA formation, the observed yields measured in these experiments represent a lower limit for PAH oxidation in the atmosphere. 

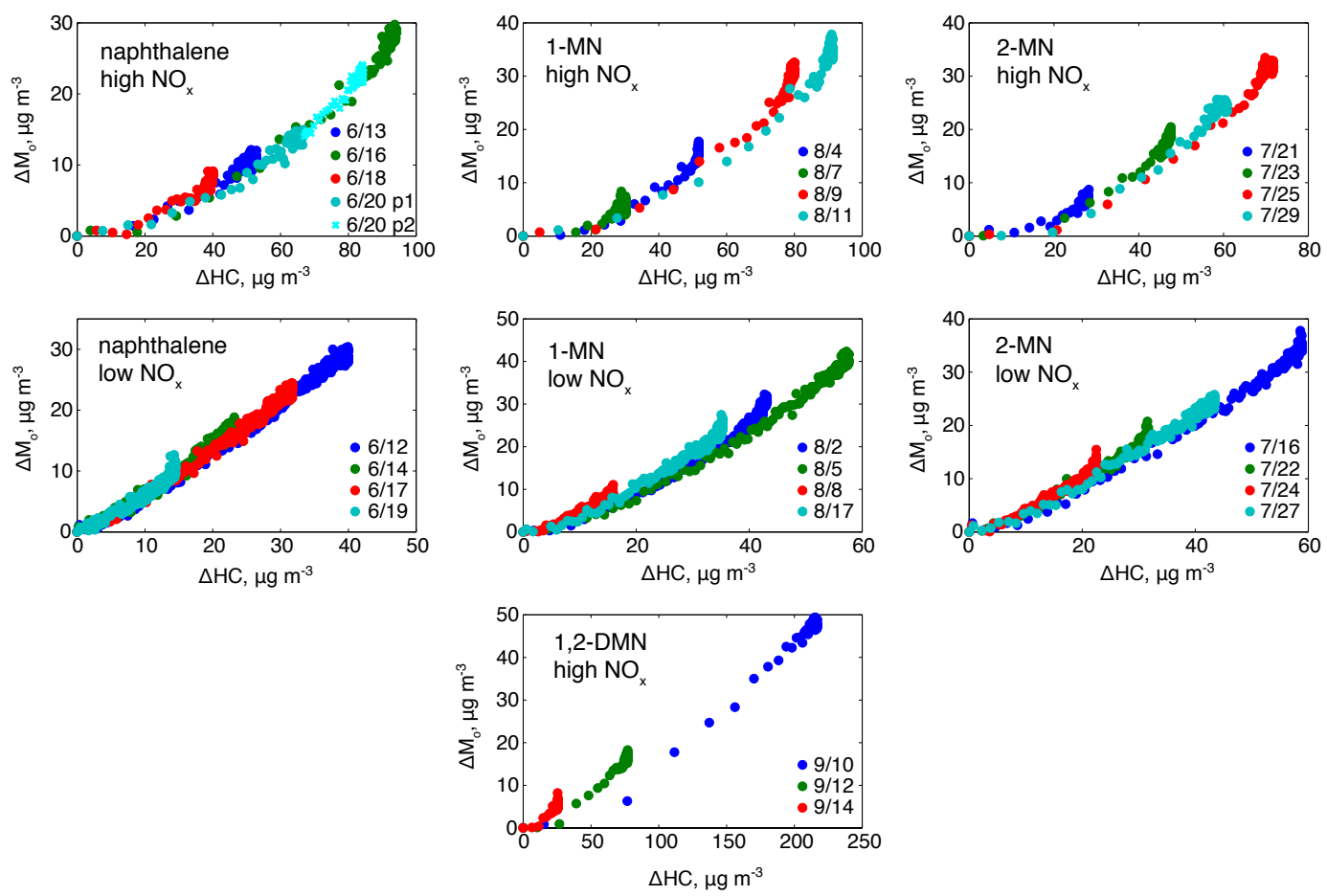

Fig. 5. Time-dependent SOA growth curves for all experiments. In one naphthalene high- $\mathrm{NO}_{\mathrm{x}}$ experiment (6/20), more $\mathrm{HONO}$ was added after the first injection was consumed. SOA growth before the second HONO addition is marked light blue and labelled " $6 / 20 \mathrm{p} 1$ ", and the growth after the second addition is marked bright cyan and labelled " $6 / 20 \mathrm{p} 2$ ".

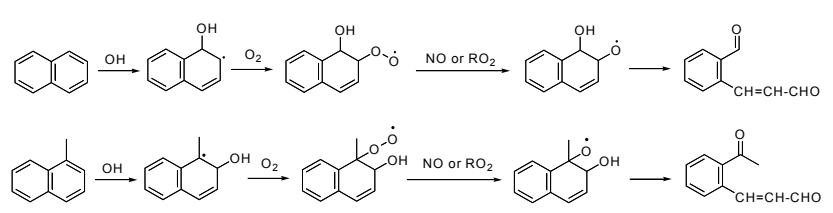

Fig. 6. Simplified mechanisms for oxidation of napthalene and $1-\mathrm{MN}$ to form first-generation dicarbonyl fragmentation products (Wang et al., 2007).

\section{2 $\mathrm{NO}_{\mathrm{x}}$ dependence of SOA growth}

In this study, the SOA yields under high- and low- $\mathrm{NO}_{\mathrm{x}}$ conditions are $25-45 \%$ and $55-75 \%$, respectively, at a total organic aerosol loading, $M_{o}$, of $15 \mu \mathrm{g} \mathrm{m}^{-3}$. This is consistent with previous studies that have shown that SOA formation is less efficient under high- $\mathrm{NO}_{\mathrm{x}}$ conditions (Kroll et al., 2006; Presto et al., 2005; $\mathrm{Ng}$ et al., 2007b), owing to formation of alkoxy radicals, followed by their decomposition. Large hydrocarbons, such as sesquiterpenes and long-chain alkanes, are exceptions to this behavior since isomerization of alkoxy radicals is more favorable (Ng et al., 2007a; Lim and Ziemann, 2005). Although the PAHs studied here also have relatively high MW, isomerization is not possible owing to the structure of the aromatic ring. As a result, fragmentation dominates under high- $\mathrm{NO}_{\mathrm{x}}$ conditions, leading to compounds that are more volatile.
The higher volatility of high- $\mathrm{NO}_{\mathrm{x}} \mathrm{SOA}$ is evidenced by the dependence of SOA yields on $M_{o}$. Under high- $\mathrm{NO}_{\mathrm{x}}$, aerosol growth was not observed until $20 \mu \mathrm{g} \mathrm{m}^{-3}$ of the parent hydrocarbon had been reacted, indicating that gas-phase oxidation products are relatively volatile. Also, with the exception of 1,2-DMN, the final SOA yields increase with increasing $M_{o}$. This is characteristic of semivolatile partitioning, in which higher organic aerosol loading induces more partitioning into the aerosol phase. Under low- $\mathrm{NO}_{\mathrm{x}}$, aerosol growth was observed almost immediately, as products have a much lower saturation concentration. The SOA yields are more or less constant, suggesting the SOA formed under low- $\mathrm{NO}_{\mathrm{x}}$ conditions is essentially nonvolatile in the range of $M_{O}$ studied here.

The gas-phase PTR mass spectra obtained under highand low- $\mathrm{NO}_{\mathrm{x}}$ photooxidation of naphthalene are shown in Fig. 3. These spectra are taken at the same fraction of naphthalene reacted, and thus the extents of reaction are similar. Figure 4 summarizes the proposed compounds for the major ion peaks based on previous gas-phase mechanistic studies (Bunce et al., 1997; Sasaki et al., 1997; Wang et al., 2007). Under high- $\mathrm{NO}_{\mathrm{x}}, 2$-formylcinnamaldehyde, phthdialadehyde, and phthalic anhydride represent the largest peaks in the mass spectrum. We refer to these compounds as "ringopening" products. Formation of these ring-opening compounds is consistent with the formation of alkoxy radicals via $\mathrm{RO}_{2}+\mathrm{NO}$ followed by decomposition of the alkoxy radicals. 
In a subsequent study, we will also show that phthalic acid, the hydrated form of phthalic anhydride, is the major product identified in the aerosol phase.

Under low- $\mathrm{NO}_{\mathrm{x}}$ conditions, these ring-opening products are formed in the absence of $\mathrm{NO}$, as $\mathrm{RO}_{2}+\mathrm{RO}_{2}$ can also form alkoxy radicals, but the relative abundance is smaller than under high- $\mathrm{NO}_{\mathrm{x}}$ conditions. Reaction of $\mathrm{RO}_{2}$ with $\mathrm{HO}_{2}$ radicals produces hydroperoxides, but owing to the lack of structural information from the PTR-MS, one cannot distinguish between the protonated hydroperoxide $\left(\mathrm{C}_{10} \mathrm{H}_{10} \mathrm{O}_{3} \cdot \mathrm{H}^{+}\right)$and the water cluster of protonated 2-formylcinnamaldehyde $\left(\mathrm{C}_{10} \mathrm{H}_{8} \mathrm{O}_{2} \cdot \mathrm{H}_{2} \mathrm{O} \cdot \mathrm{H}^{+}\right)$. However, the relative abundance of other "ring-retaining" products, such as epoxides, naphthols, and quinones, is greater, likely because formation of the alkoxy radical is no longer dominant. Since these compounds and their oxidation products likely have a higher MW than ring-opening products, their volatilities are lower, resulting in the overall low volatility of SOA formed and essentially constant yields under low- $\mathrm{NO}_{\mathrm{x}}$ conditions. It is also possible that the relatively lower concentrations of ringopening products under low- $\mathrm{NO}_{\mathrm{x}}$ are a result of longer UV exposure time. The $\mathrm{OH}$ concentrations are a factor of 5 lower under low- $\mathrm{NO}_{\mathrm{x}}$ conditions. A longer irradiation time is needed to achieve the same fraction of naphthalene reacted, resulting in greater loss of 2-formylcinnamaldehyde by photolysis (Nishino et al., 2009).

\subsection{Aerosol formation and yields}

A widely-used semi-empirical model for SOA formation is based on the gas-particle equilibrium partitioning of semivolatile products (Odum et al., 1996, 1997), in which the SOA yield, $Y$, of a particular VOC, defined as the ratio of mass of SOA formed, $\Delta M_{o}$, to the mass of hydrocarbon reacted, $\triangle H C$, is given by

$Y=\frac{\Delta M_{o}}{\Delta H C}=M_{o} \sum_{i=1}^{n} \frac{\alpha_{i} K_{p, i}}{1+K_{p, i} M_{o}}$

where $\alpha_{i}$ is the mass-based stoichiometric coefficient of semivolatile product $i, K_{p, i}$ is its gas-particle partitioning equilibrium constant, and $M_{O}$ is the total mass concentration of the absorbing (aerosol) medium. In this study, since no organic aerosol seed was used, the total organic mass is equal to the mass of SOA formed $\left(M_{o}=\Delta M_{o}\right)$. The final SOA yields for all experiments have been fitted to Eq. (1) for naphthalene, 1-MN and 2-MN photooxidation under high$\mathrm{NO}_{\mathrm{x}}$ conditions, shown in Fig. 7. For naphthalene, a twoproduct model was used; for 1-MN and 2-MN, one product is sufficient to describe the experimental data. For 1,2DMN under high- $\mathrm{NO}_{\mathrm{x}}$, and all other PAHs under low $\mathrm{NO}_{\mathrm{x}}$, the SOA yields are constant. The fitting parameters are summarized in Table 3. The SOA yields for naphthalene and alkylnaphthalenes quantified in this study are on the order of $25-45 \%$ under high- $\mathrm{NO}_{\mathrm{x}}$ conditions, which are about three

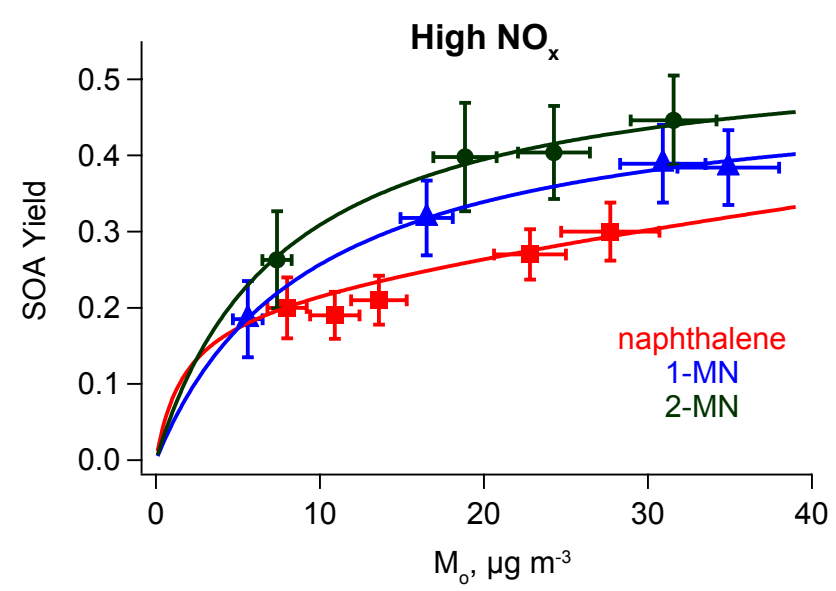

Fig. 7. SOA yield as a function of organic loading for naphthalene, $1-\mathrm{MN}$ and $2-\mathrm{MN}$ under high- $\mathrm{NO}_{\mathrm{x}}$ conditions. The fitting parameters used are summarized in Table 3 . Under low- $\mathrm{NO}_{\mathrm{x}}$ conditions, the SOA yields are essentially constant.

times those for light aromatics under similar photooxidation conditions (Ng et al., 2007b).

\section{Estimation of SOA production from light aromatics, PAH and long-chain $n$-alkanes}

Using the compounds studied here as surrogates for PAHs, we estimate the contribution of PAH photooxidation to urban SOA formation from different anthropogenic sources.

\subsection{Diesel exhaust}

Diesel exhaust is an important source of POA in the urban atmosphere (Schauer et al., 1996). As noted above, diesel exhaust, upon photooxidation, is also an SOA source (Robinson et al., 2007). The gas-phase component of diesel emissions consists primarily of light aromatics, PAHs and longchain $n$-alkanes (Schauer et al., 1999a). For compound $i$ emitted in the gas phase, the amount of SOA formed from photooxidation of that compound, $\Delta M_{o, i}$, expressed in units of $\mu \mathrm{g} \mathrm{km}^{-1}$, over a time $\Delta t$, can be estimated by

$\Delta M_{o, i}=\left[H C_{i}\right]\left(1-e^{-k_{\mathrm{OH}, i}[\mathrm{OH}] \Delta t}\right) \times Y_{i}$

where $H C_{i}$ is the amount of gas-phase emission of compound $i$ in $\mu \mathrm{g} \mathrm{km}^{-1}, k_{\mathrm{OH}, i}$ is its reaction rate constant with $\mathrm{OH}$ radicals, $[\mathrm{OH}]$ is the concentration of $\mathrm{OH}$ radicals (taken to be $2 \times 10^{6} \mathrm{molec}^{-3}$ ) and $Y_{i}$ is its SOA yield. To obtain a specific value of $Y_{i}$, we assume a total organic aerosol loading of $15 \mu \mathrm{g} \mathrm{m}^{-3}$. Emissions of each compound (and hence the amount of SOA formed), measured in $\mu \mathrm{g}$ per km driven, are taken from Schauer et al. (1999a). $\mathrm{OH}$ reaction rate constants are taken from literature where available (Atkinson and Arey, 2003; Phousongphouang and 
Table 3. SOA yield parameters.

\begin{tabular}{lccccc}
\hline & $\alpha_{1}$ & $K_{1}, \mathrm{~m}^{3} \mu \mathrm{g}^{-1}$ & $\alpha_{2}$ & $K_{2}, \mathrm{~m}^{3} \mu \mathrm{g}^{-1}$ & Yield at $M_{o}=15 \mu \mathrm{g} \mathrm{m}^{-3}$ \\
\hline high-NO x & & & & & \\
naphthalene & 0.21 & 0.59 & 1.07 & 0.0037 & 0.26 \\
1-MN & 0.50 & 0.11 & - & - & 0.33 \\
2-MN & 0.55 & 0.13 & - & - & 0.38 \\
1,2-DMN & 0.31 & $\mathrm{a}$ & - & - & 0.31 \\
& & & & & \\
low-NOx & & & - & - & 0.73 \\
naphthalene & 0.73 & $\mathrm{a}$ & - & - & 0.68 \\
1-MN & 0.68 & $\mathrm{a}$ & - & - & 0.58 \\
2-MN & 0.58 & $\mathrm{a}$ & - & & \\
\hline
\end{tabular}

${ }^{\text {a }}$ Constant yield

Arey, 2002), or estimated from structure activity relationships (Kwok and Atkinson, 1995) or extrapolation from similar compounds. The high- $\mathrm{NO}_{\mathrm{x}} \mathrm{SOA}$ yields measured here are used in this analysis. For purpose of comparison, we use the SOA yields for benzene, toluene and $m$-xylene measured under similar photooxidation conditions $(\mathrm{OH}$ precursor, concentrations of $\mathrm{NO}_{\mathrm{x}}$ and light intensity) ( $\mathrm{Ng}$ et al., 2007b). SOA yields for $n$-alkanes were estimated based on modeling of gas-phase radical chemistry and gas-particle partitioning (Lim and Ziemann, 2005; Jordan et al., 2008).

Table 4 summarizes the contribution of each VOC identified to the total SOA formed from gas-phase photooxidation of these three classes of compounds. Although the gas-phase emissions are dominated by light aromatics, these compounds are estimated to account for only $14 \%$ of the SOA formed in first $3 \mathrm{~h}$ of photooxidation. This estimate is consistent with laboratory results of photooxidation of diesel exhaust (Robinson et al., 2007), in which the "known" gasphase precursors, consisting primarily of single-ring aromatics, account for at most $15 \%$ of the SOA formed. In addition to their relatively low SOA yields, the rate of oxidation of these compounds is slow, and hence only a small fraction is reacted over $3 \mathrm{~h}$. On the contrary, although PAH emissions are a factor of 4 lower than those of light aromatics, their relatively fast reaction with $\mathrm{OH}$ radicals and high SOA yields lead to significant SOA production in the first $3 \mathrm{~h}$, accounting for 4 times the amount formed from light aromatics. The contribution of PAH to SOA is still significant after $12 \mathrm{~h}$ of oxidation, at which point the SOA from PAH is about twice that from light aromatics.

To estimate the SOA production from diesel exhaust over longer timescales $(>12 \mathrm{~h}$ ), we assume that the reaction time is sufficiently long that all of the hydrocarbon has been consumed by reaction with $\mathrm{OH}$ radicals (ignoring nighttime chemistry and deposition of gas-phase hydrocarbons). This also allows for the air mass to be transported away from the sources, where the $\mathrm{NO}_{\mathrm{x}}$ levels are lower and aromatic com- pounds are expected to produce SOA at higher mass yields (Henze et al., 2008; Ng et al., 2007b). To account for the difference in SOA formation from light aromatics between high- and low- $\mathrm{NO}_{\mathrm{x}}$ pathways, we use the branching ratios calculated by Henze et al. (2008) for benzene, toluene and $m$-xylene. Because naphthalene has a similar $\mathrm{OH}$ rate as $m$ xylene, we use the same branching ratio for naphthalene. For all other PAHs, we assume they all react under high- $\mathrm{NO}_{\mathrm{x}}$ as a conservative estimate. For $n$-alkanes, since their low- $\mathrm{NO}_{\mathrm{x}}$ yields are not known, they are not included in this part of the analysis. We caution readers that this is a zeroth order to compare SOA formation of light aromatics and PAHs over longer timescales. Multi-generation oxidation chemistry and aerosol aging will play an as yet undetermined role beyond the timescale over which these SOA yields were measured. Nonetheless, over very long timescales, the contribution of PAHs to overall SOA production is about half that of light aromatics (see Table 4).

Another important class of primary compounds is $n$ alkanes, which have been shown to have significant aerosol yields under high- $\mathrm{NO}_{\mathrm{x}}$ conditions if the number of carbons is greater than 8 (Lim and Ziemann, 2005). In this calculation, SOA production from long-chain $n$-alkanes ranging from $C_{12}$ to $C_{20}$ is estimated to be higher than from light aromatics by a factor of 1.5 for the first $3 \mathrm{~h}$. Only a small fraction of the compounds present in diesel emissions are speciated in Schauer et al. (1999a), but considering only these three classes of compounds, PAHs are estimated to account for up to $54 \%$ of the SOA formed in the first $12 \mathrm{~h}$ of diesel exhaust photooxidation, representing a potentially large source of atmospheric SOA.

\subsection{Wood burning}

Wood burning has also been shown to produce a significant amount of SOA that cannot be accounted for by known volatile precursors (Grieshop et al., 2009b). Gas-phase emissions of aromatic compounds from fireplace wood burning 
Table 4. Estimated SOA production from gas-phase oxidation of diesel exhaust (Schauer et al., 1999a).

\begin{tabular}{|c|c|c|c|c|c|c|c|}
\hline & $\begin{array}{c}{\left[H C_{i}\right]} \\
\mu \mathrm{g} \mathrm{km}^{-1}\end{array}$ & $\begin{array}{c}k_{\mathrm{OH}}, \\
\mathrm{cm}^{3} \mathrm{molec}^{-1} \mathrm{~s}^{-1}\end{array}$ & $\begin{array}{c}Y \\
\text { (high- } \mathrm{NO}_{\mathrm{x}} \text { ) }\end{array}$ & $\begin{array}{c}\Delta t=3 \mathrm{~h} \\
\Delta M_{o, i}, \mu \mathrm{g} \mathrm{km}^{-1}\end{array}$ & $\begin{array}{c}\Delta t=12 \mathrm{~h} \\
\Delta M_{o, i}, \mu \mathrm{g} \mathrm{km}^{-1}\end{array}$ & $\begin{array}{c}Y \\
\left(\text { low- } \mathrm{NO}_{\mathrm{x}}\right)\end{array}$ & $\begin{array}{c}\Delta t=\infty \\
\Delta M_{o, i}, \mu \mathrm{g} \mathrm{km}^{-1}\end{array}$ \\
\hline \multicolumn{8}{|l|}{ light aromatics } \\
\hline benzene & 2740 & $1.22 \times 10^{-12 \mathrm{a}}$ & $0.19^{f}$ & 14 & 53 & $0.37^{\mathrm{f}}$ & 778 \\
\hline toluene & 3980 & $5.63 \times 10^{-12 a}$ & $0.10^{\mathrm{f}}$ & 47 & 158 & $0.3^{\mathrm{f}}$ & 700 \\
\hline ethylbenzene & 470 & $7.00 \times 10^{-12 a}$ & $0.10^{\mathrm{g}}$ & 7 & 22 & $0.3^{\mathrm{g}}$ & 83 \\
\hline xylene & 2330 & $1.36 \times 10^{-11 \mathrm{a}}$ & $0.06^{\mathrm{h}}$ & 35 & 96 & $0.36^{\mathrm{h}}$ & 321 \\
\hline$o$-xylene & 830 & $2.31 \times 10^{-11 \mathrm{a}}$ & $0.06^{\mathrm{h}}$ & 19 & 43 & $0.36^{\mathrm{h}}$ & 114 \\
\hline$n$-propylbenzene & 100 & $1.43 \times 10^{-11 \mathrm{a}}$ & $0.10^{\mathrm{g}}$ & 3 & 7 & $0.3^{g}$ & 18 \\
\hline$p$-ethyltoluene & 520 & $1.18 \times 10^{-11 \mathrm{a}}$ & $0.10^{\mathrm{g}}$ & 12 & 34 & $0.3^{\mathrm{g}}$ & 92 \\
\hline$m$-ethyltoluene & 210 & $1.86 \times 10^{-11 \mathrm{a}}$ & $0.10^{\mathrm{g}}$ & 7 & 17 & $0.3^{\mathrm{g}}$ & 37 \\
\hline 1,3,5-TMB & 260 & $5.67 \times 10^{-11 \mathrm{a}}$ & $0.06^{\mathrm{h}}$ & 11 & 15 & $0.36^{\mathrm{h}}$ & 36 \\
\hline 1,2,4-TMB & 880 & $3.25 \times 10^{-11 \mathrm{a}}$ & $0.06^{\mathrm{h}}$ & 27 & 49 & $0.36^{\mathrm{h}}$ & 121 \\
\hline Total & & & & 182 & 496 & & 2300 \\
\hline \multicolumn{8}{|l|}{ PAHs } \\
\hline naphthalene & 617 & $2.30 \times 10^{-11 \mathrm{a}}$ & 0.26 & 62 & 136 & 0.73 & 234 \\
\hline 2-methylnaphthalene & 611 & $4.86 \times 10^{-11 b}$ & 0.38 & 152 & 231 & $\mathrm{k}$ & 231 \\
\hline 1-methylnaphthalene & 378 & $4.09 \times 10^{-11 b}$ & 0.33 & 73 & 120 & $\mathrm{k}$ & 120 \\
\hline C2-naphthalenes & 542 & $6.00 \times 10^{-11 \mathrm{c}}$ & 0.31 & 122 & 167 & $\mathrm{k}$ & 167 \\
\hline C3-naphthalenes & 240 & $8.00 \times 10^{-11 d}$ & 0.31 & 61 & 74 & $\mathrm{k}$ & 74 \\
\hline C4-naphthalenes & 97.3 & $8.00 \times 10^{-11 \mathrm{~d}}$ & 0.31 & 25 & 30 & $\mathrm{k}$ & 30 \\
\hline other PAHs & 886.7 & $8.00 \times 10^{-11 d}$ & 0.31 & 226 & 275 & $\mathrm{k}$ & 275 \\
\hline Total & & & & 721 & 1033 & & 1131 \\
\hline \multicolumn{8}{|l|}{ n-alkanes } \\
\hline dodecane & 503 & $1.32 \times 10^{-11 \mathrm{a}}$ & $0.02^{\mathrm{i}}$ & 2 & 5 & & \\
\hline tridecane & 477 & $1.51 \times 10^{-11 \mathrm{a}}$ & $0.03^{\mathrm{i}}$ & 4 & 10 & & \\
\hline tetradecane & 629 & $1.79 \times 10^{-11 \mathrm{a}}$ & $0.05^{\mathrm{i}}$ & 10 & 23 & & \\
\hline pentadecane & 398 & $2.07 \times 10^{-11 \mathrm{a}}$ & $0.08^{\mathrm{i}}$ & 11 & 25 & & \\
\hline hexadecane & 711 & $2.32 \times 10^{-11 \mathrm{a}}$ & $0.12^{\mathrm{i}}$ & 34 & 75 & & \\
\hline heptadecane & 614 & $2.85 \times 10^{-11 \mathrm{e}}$ & $0.20^{\mathrm{i}}$ & 55 & 110 & & \\
\hline octadecane & 601 & $3.51 \times 10^{-11 \mathrm{e}}$ & $0.30^{\mathrm{j}}$ & 96 & 172 & & \\
\hline nonadecane & 411 & $4.32 \times 10^{-11 \mathrm{e}}$ & $0.42^{\mathrm{j}}$ & 105 & 168 & & \\
\hline eicosane & 271.8 & $5.31 \times 10^{-11 \mathrm{e}}$ & $0.56^{\mathrm{j}}$ & 104 & 151 & & \\
\hline Total & & & & 420 & 740 & & \\
\hline
\end{tabular}

a Atkinson and Arey (2003); ${ }^{b}$ Phousongphouang and Arey (2002); ${ }^{c}$ Average of all dimethylnaphthalanes in Phousongphouang and Arey (2002); ${ }^{\mathrm{d}}$ Extrapolated from dimethylnaphthalenes, assumed to be same for all other PAHs; ${ }^{\mathrm{e}}$ Estimated from structure-reactivity relationships (Kwok and Atkinson, 1995); ${ }^{\mathrm{f}} \mathrm{Ng}$ et al. (2007b); ${ }^{\mathrm{g}}$ Assumed to be the same as toluene; ${ }^{\mathrm{h}}$ Assumed to be the same as $m$-xylene; ${ }^{\mathrm{i}}$ Estimated from modeling of gas-phase chemistry and gas/particle partitioning (Jordan et al., 2008); ${ }^{\mathrm{j}}$ Extrapolated from smaller $n$-alkanes; ${ }^{\mathrm{k}}$ Assume all reacted under high- $\mathrm{NO}_{\mathrm{X}}$

are detailed in Schauer et al. (2001), in which $90 \%$ of the emissions (by mass) were identified. The gas-phase composition of wood combustion emissions depends on temperature, type of fuel, and method of burning (open vs. fireplace), and quantifying SOA from such sources can be difficult. Nonetheless, we repeat the previous analysis, and Table 5 summarizes the estimated SOA production from light aromatics and PAHs from fireplace burning of pine wood. Again, despite their relatively low emissions, the high SOA yields and rapid rate of oxidation of PAHs result in higher SOA formation over shorter timescales. The amount of SOA from PAHs is estimated to be more than 4 times that from light aromatics after $12 \mathrm{~h}$ of oxidation, suggesting a poten- tially large source of SOA from oxidation of wood burning emissions. Assuming the SOA yields do not change, PAHs contribute a comparable amount of SOA to light aromatics over very long timescales.

\subsection{Other anthropogenic sources}

For gasoline exhaust, the emissions of PAHs relative to light aromatics are low such that their contribution to SOA formation is likely insignificant (Schauer et al., 2002a). For other sources, such as meat and seed oil cooking, the emissions of light aromatics and PAHs are insignificant (Schauer et al., 1999b, 2002b). One class of compounds not addressed in this 
Table 5. Estimated SOA production from gas-phase oxidation of emissions from fireplace burning of pine wood (Schauer et al., 2001)

\begin{tabular}{|c|c|c|c|c|c|c|}
\hline & $\begin{array}{c}{\left[H C_{i}\right]} \\
\mathrm{mg} \mathrm{kg}^{-1}\end{array}$ & $\begin{array}{c}k_{\mathrm{OH}} \\
\mathrm{cm}^{3} \text { molec }^{-1} \mathrm{~s}^{-1}\end{array}$ & $\begin{array}{c}Y \\
\left(\text { high- } \mathrm{NO}_{\mathrm{x}}\right)\end{array}$ & $\begin{array}{c}\Delta t=12 \mathrm{~h} \\
\Delta M_{o, i}, \mathrm{mg} \mathrm{kg}^{-1}\end{array}$ & $\begin{array}{c}Y \\
\left(\text { low- } \mathrm{NO}_{\mathrm{x}}\right)\end{array}$ & $\begin{array}{c}\Delta t=\infty \\
\Delta M_{o, i}, \mathrm{mg} \mathrm{kg}^{-1}\end{array}$ \\
\hline \multicolumn{7}{|l|}{ light aromatics } \\
\hline benzene & 383 & $1.22 \times 10^{-12}$ & 0.19 & 7.5 & 0.37 & 108.8 \\
\hline toluene & 158 & $5.63 \times 10^{-12}$ & 0.10 & 6.3 & 0.3 & 27.8 \\
\hline ethylbenzene & 22.9 & $7.00 \times 10^{-12}$ & 0.10 & 1.1 & 0.3 & 4.0 \\
\hline xylene & 60 & $1.36 \times 10^{-11}$ & 0.06 & 2.5 & 0.36 & 8.3 \\
\hline$o$-xylene & 18.1 & $2.31 \times 10^{-11}$ & 0.06 & 0.9 & 0.36 & 2.5 \\
\hline Total & & & & 18.2 & & 151.4 \\
\hline \multicolumn{7}{|l|}{$P A H s$} \\
\hline naphthalene & 227 & $2.30 \times 10^{-11}$ & 0.26 & 50.0 & 0.73 & 86.0 \\
\hline 2-methylnaphthalene & 15 & $4.86 \times 10^{-11}$ & 0.38 & 5.7 & - & 5.7 \\
\hline 1-methylnaphthalene & 10.6 & $4.09 \times 10^{-11}$ & 0.33 & 3.4 & - & 3.4 \\
\hline C2-naphthalenes & 13.8 & $6.00 \times 10^{-11}$ & 0.31 & 4.3 & - & 4.3 \\
\hline other PAHs & 63.7 & $8.00 \times 10^{-11}$ & 0.31 & 19.7 & - & 19.7 \\
\hline Total & & & & 80.9 & & 119.0 \\
\hline
\end{tabular}

analysis is $n-\mathrm{C}_{10}-\mathrm{C}_{14}$ aldehydes, which are emitted in significant quantities from each of the sources considered here. To the authors' knowledge, SOA yields for these compounds have not been quantified and could potentially contribute to urban SOA formation.

We stress that the analysis presented here constitutes a first-order estimate of SOA production from PAHs. The calculations are based on emissions measured from single sources, rather than on overall emissions inventories. Future work will address the prediction of SOA formation based on atmospheric emissions inventories of gas-phase PAHs.

\section{Implications}

In this study, we have investigated the formation of SOA from gas-phase photooxidation of four 2-ring PAHs (naphthalene, 1-MN, 2-MN and 1,2-DMN) under high- and low$\mathrm{NO}_{\mathrm{x}}$ conditions. Under high- $\mathrm{NO}_{\mathrm{x}}$ and at organic aerosol loadings between 10 and $40 \mu \mathrm{g} \mathrm{m}^{-3}$, SOA yields ranged from 0.19 to 0.30 for naphthalene, 0.19 to 0.39 for $1-\mathrm{MN}$ and 0.26 to 0.45 for 2-MN. The SOA products were found to be semivolatile, consistent with the gas-phase products being dominated by ring-opening compounds. Under low- $\mathrm{NO}_{\mathrm{x}}$ conditions, the SOA yield was found to be constant in the range of $M_{o}$ studied, and was measured to be $0.73,0.68$, and 0.58 , for naphthalene, $1-\mathrm{MN}$, and 2-MN, respectively. More ring-retaining products were found in the gas phase under low- $\mathrm{NO}_{\mathrm{x}}$ conditions, contributing to the low volatility of the SOA and constant SOA yields. The SOA formed from high$\mathrm{NO}_{\mathrm{x}}$ photooxidation of 1,2-DMN was also nonvolatile under these loadings.
When applying these measured yields to a simple model of SOA formation from primary emissions, SOA from PAH oxidation is found to contribute a significant amount. Traditionally thought to be the most important anthropogenic SOA precursors, light aromatics are estimated to produce 3-5 times less SOA than from PAHs, based on the emissions inventories employed here. PAHs represent a potentially large source of urban SOA, accounting for up to 54\% of SOA formed from diesel exhaust, and up to $80 \%$ of SOA from fireplace wood burning. Over longer timescales, PAHs are expected to contribute a nonnegligible amount of SOA. Long-chain $n$-alkanes are also expected to produce a smaller but significant fraction of SOA from diesel exhaust.

To properly account for SOA formation from anthropogenic sources, photooxidation of low-volatility precursors, such as PAH and $n$-alkanes, should be included in atmospheric SOA models, likely increasing the amount of predicted anthropogenic SOA significantly. Other IVOCs, such as aliphatic aldehydes and large olefins, could also be an important source of SOA, but further study is required to evaluate their potential to form SOA. In a forthcoming study, we will examine the mechanism of PAH oxidation and the composition of the SOA generated from the experiments reported here to assess the atmospheric relevance of these results.

Acknowledgements. This research was funded by the Office of Science (BER), US Department of Energy Grant No. DE-FG0205ER63983, US Environmental Protection Agency STAR Research Assistance Agreement No. RD-83374901 and US National Science Foundation grant ATM-0432377. This publication has not been formally reviewed by the EPA. The views expressed in this document are solely those of the authors and EPA does not endorse any products mentioned in this publication. The authors would like 
to thank D. R. Fitz for use of $\mathrm{GC} / \mathrm{NO}_{2}-\mathrm{PAN}$ analyzer, L. D. Yee for assistance with running experiments, and C. E. Jordan for helpful discussion.

Edited by: J. Abbatt

\section{References}

Arey, J., Atkinson, R., Zielinska, B., and Mcelroy, P. A.: Diurnal concentrations of volatile polycyclic aromatic-hydrocarbons and nitroarenes during a photochemical air-pollution episode in Glendora, California, Environ. Sci. Technol., 23, 321-327, 1989.

Atkinson, R. and Arey, J.: Atmospheric degradation of volatile organic compounds, Chem. Rev., 103, 4605-4638, 2003.

Atkinson, R., Arey, J., Zielinska, B., and Aschmann, S. M.: Kinetics and products of the gas-phase reactions of $\mathrm{OH}$ radicals and $\mathrm{N}_{2} \mathrm{O}_{5}$ with naphthalene and biphenyl, Environ. Sci. Technol., 21, 1014-1022, 1987.

Bahreini, R., Keywood, M. D., Ng, N. L., Varutbangkul, V., Gao, S., Flagan, R. C., Seinfeld, J. H., Worsnop, D. R., and Jimenez, J. L.: Measurements of secondary organic aerosol from oxidation of cycloalkenes, terpenes, and $m$-xylene using an Aerodyne aerosol mass spectrometer, Environ. Sci. Technol., 39, 5674-5688, 2005.

Bunce, N. J., Liu, L., Zhu, J., and Lane, D. A.: Reaction of naphthalene and its derivatives with hydroxyl radicals in the gas phase, Environ. Sci. Technol., 31, 2252-2259, 1997.

Burkhardt, M. R., Maniga, N. I., Stedman, D. H., and Paur, R. J.: Gas-chromatographic method for measuring nitrogen-dioxide and peroxyacetyl nitrate in air without compressed gas-cylinders, Anal. Chem., 60, 816-819, 1988.

Chan, A. W. H., Kroll, J. H., Ng, N. L., and Seinfeld, J. H.: Kinetic modeling of secondary organic aerosol formation: effects of particle- and gas-phase reactions of semivolatile products, Atmos. Chem. Phys., 7, 4135-4147, 2007, http://www.atmos-chem-phys.net/7/4135/2007/.

Cocker, D. R., Flagan, R. C., and Seinfeld, J. H.: State-of-the-art chamber facility for studying atmospheric aerosol chemistry, Environ. Sci. Technol., 35, 2594-2601, 2001.

de Gouw, J. A., Middlebrook, A. M., Warneke, C., Goldan, P. D., Kuster, W. C., Roberts, J. M., Fehsenfeld, F. C., Worsnop, D. R., Canagaratna, M. R., Pszenny, A. A. P., Keene, W. C., Marchewka, M., Bertman, S. B., and Bates, T. S.: Budget of organic carbon in a polluted atmosphere: Results from the New England Air Quality Study in 2002, J. Geophys. Res.-Atmos., 110, doi:10.1029/2004JD005623, 2005.

DeCarlo, P. F., Kimmel, J. R., Trimborn, A., Northway, M. J., Jayne, J. T., Aiken, A. C., Gonin, M., Fuhrer, K., Horvath, T., Docherty, K. S., Worsnop, D. R., and Jimenez, J. L.: Field-deployable, high-resolution, time-of-flight aerosol mass spectrometer, Anal. Chem., 78, 8281-8289, 2006.

Docherty, K. S., Stone, E. A., Ulbrich, I. M., DeCarlo, P. F., Snyder, D. C., Schauer, J. J., Peltier, R. E., Weber, R. J., Murphy, S. M., Seinfeld, J. H., Grover, B. D., Eatough, D. J., and Jimenez, J. L.: Apportionment of primary and secondary organic aerosols in southern California during the 2005 Study of Organic Aerosols in Riverside (SOAR-1), Environ. Sci. Technol., 42, 7655-7662, 2008.

Donahue, N. M., Robinson, A. L., and Pandis, S. N.: Atmospheric organic particulate matter: From smoke to secondary organic aerosol, Atmos. Environ., 43, 94-106, 2009.

Goldstein, A. H. and Galbally, I. E.: Known and unexplored organic constituents in the earth's atmosphere, Environ. Sci. Technol., 41, 1514-1521, 2007.

Grieshop, A. P., Donahue, N. M., and Robinson, A. L.: Laboratory investigation of photochemical oxidation of organic aerosol from wood fires 2: analysis of aerosol mass spectrometer data, Atmos. Chem. Phys., 9, 2227-2240, 2009a, http://www.atmos-chem-phys.net/9/2227/2009/.

Grieshop, A. P., Logue, J. M., Donahue, N. M., and Robinson, A. L.: Laboratory investigation of photochemical oxidation of organic aerosol from wood fires 1: measurement and simulation of organic aerosol evolution, Atmos. Chem. Phys., 9, 1263-1277, 2009b, http://www.atmos-chem-phys.net/9/1263/2009/.

Heald, C. L., Jacob, D. J., Park, R. J., Russell, L. M., Huebert, B. J., Seinfeld, J. H., Liao, H., and Weber, R. J.: A large organic aerosol source in the free troposphere missing from current models, Geophys. Res. Lett., 32, doi:10.1029/2005GL023831, 2005.

Henze, D. K., Seinfeld, J. H., Ng, N. L., Kroll, J. H., Fu, T.-M., Jacob, D. J., and Heald, C. L.: Global modeling of secondary organic aerosol formation from aromatic hydrocarbons: highvs. low-yield pathways, Atmos. Chem. Phys., 8, 2405-2420, 2008, http://www.atmos-chem-phys.net/8/2405/2008/.

Jordan, C. E., Ziemann, P. J., Griffin, R. J., Lim, Y. B., Atkinson, R., and Arey, J.: Modeling SOA formation from $\mathrm{OH}$ reactions with C8-C17 n-alkanes, Atmos. Environ., 42, 8015-8026, 2008.

Keywood, M. D., Varutbangkul, V., Bahreini, R., Flagan, R. C., and Seinfeld, J. H.: Secondary organic aerosol formation from the ozonolysis of cycloalkenes and related compounds, Environ. Sci. Technol., 38, 4157-4164, 2004.

Kroll, J. H., Ng, N. L., Murphy, S. M., Flagan, R. C., and Seinfeld, J. H.: Secondary organic aerosol formation from isoprene photooxidation, Environ. Sci. Technol., 40, 1869-1877, 2006.

Kwok, E. S. C. and Atkinson, R.: Estimation of hydroxyl radical reaction-rate constants for gas-phase organic-compounds using a structure-reactivity relationship - an update, Atmos. Environ., 29, 1685-1695, 1995.

Lim, Y. B. and Ziemann, P. J.: Products and mechanism of secondary organic aerosol formation from reactions of $n$-alkanes with $\mathrm{OH}$ radicals in the presence of $\mathrm{NO}_{\mathrm{x}}$, Environ. Sci. Technol., 39, 9229-9236, 2005.

Mihele, C. M., Wiebe, H. A., and Lane, D. A.: Particle formation and gas/particle partition measurements of the products of the naphthalene-OH radical reaction in a smog chamber, Polycycl. Aromat. Comp., 22, 729-736, 2002.

Ng, N. L., Kroll, J. H., Keywood, M. D., Bahreini, R., Varutbangkul, V., Flagan, R. C., Seinfeld, J. H., Lee, A., and Goldstein, A. H.: Contribution of first- versus second-generation products to secondary organic aerosols formed in the oxidation of biogenic hydrocarbons, Environ. Sci. Technol., 40, 2283-2297, 2006.

Ng, N. L., Chhabra, P. S., Chan, A. W. H., Surratt, J. D., Kroll, J. H., Kwan, A. J., McCabe, D. C., Wennberg, P. O., Sorooshian, A., Murphy, S. M., Dalleska, N. F., Flagan, R. C., and Seinfeld, J. H.: Effect of $\mathrm{NO}_{\mathrm{x}}$ level on secondary organic aerosol (SOA) formation from the photooxidation of terpenes, Atmos. Chem. Phys., 7, 5159-5174, 2007a, http://www.atmos-chem-phys.net/7/5159/2007/.

Ng, N. L., Kroll, J. H., Chan, A. W. H., Chhabra, P. S., Flagan, 
R. C., and Seinfeld, J. H.: Secondary organic aerosol formation from m-xylene, toluene, and benzene, Atmos. Chem. Phys., 7, 3909-3922, 2007b,

http://www.atmos-chem-phys.net/7/3909/2007/.

Nishino, N., Atkinson, R., and Arey, J.: Formation of nitro products from the gas-phase $\mathrm{OH}$ radical-initiated reactions of toluene, naphthalene, and biphenyl: effect of $\mathrm{NO}_{2}$ concentration, Environ. Sci. Technol., 42, 9203-9209, 2008.

Nishino, N., Arey, J., and Atkinson, R.: Formation and reactions of 2-Formylcinnamaldehyde in the $\mathrm{OH}$ radical-initiated reaction of naphthalene, Environ. Sci. Technol., 43, 1349-1353, 2009.

Odum, J. R., Hoffmann, T., Bowman, F., Collins, D., Flagan, R. C., and Seinfeld, J. H.: Gas/particle partitioning and secondary organic aerosol yields, Environ. Sci. Technol., 30, 2580-2585, 1996.

Odum, J. R., Jungkamp, T. P. W., Griffin, R. J., Flagan, R. C., and Seinfeld, J. H.: The atmospheric aerosol-forming potential of whole gasoline vapor, Science, 276, 96-99, 1997.

Phousongphouang, P. T. and Arey, J.: Rate constants for the gasphase reactions of a series of alkylnaphthalenes with the $\mathrm{OH}$ radical, Environ. Sci. Technol., 36, 1947-1952, 2002.

Presto, A. A., Hartz, K. E. H., and Donahue, N. M.: Secondary organic aerosol production from terpene ozonolysis. 2. Effect of $\mathrm{NO}_{\mathrm{x}}$ concentration, Environ. Sci. Technol., 39, 7046-7054, 2005.

Robinson, A. L., Donahue, N. M., Shrivastava, M. K., Weitkamp, E. A., Sage, A. M., Grieshop, A. P., Lane, T. E., Pierce, J. R., and Pandis, S. N.: Rethinking organic aerosols: Semivolatile emissions and photochemical aging, Science, 315, 1259-1262, 2007.

Sage, A. M., Weitkamp, E. A., Robinson, A. L., and Donahue, N. M.: Evolving mass spectra of the oxidized component of organic aerosol: results from aerosol mass spectrometer analyses of aged diesel emissions, Atmos. Chem. Phys., 8, 1139-1152, 2008, http://www.atmos-chem-phys.net/8/1139/2008/.

Sasaki, J., Aschmann, S. M., Kwok, E. S. C., Atkinson, R., and Arey, J.: Products of the gas-phase $\mathrm{OH}$ and $\mathrm{NO}_{3}$ radical-initiated reactions of naphthalene, Environ. Sci. Technol., 31, 3173-3179, 1997.

Schauer, J. J., Rogge, W. F., Hildemann, L. M., Mazurek, M. A., and Cass, G. R.: Source apportionment of airborne particulate matter using organic compounds as tracers, Atmos. Environ., 30, 3837-3855, 1996.

Schauer, J. J., Kleeman, M. J., Cass, G. R., and Simoneit, B. R. T.: Measurement of emissions from air pollution sources. 2. C1 through C-30 organic compounds from medium duty diesel trucks, Environ. Sci. Technol., 33, 1578-1587, 1999a.
Schauer, J. J., Kleeman, M. J., Cass, G. R., and Simoneit, B. R. T.: Measurement of emissions from air pollution sources. 1. C-1 through C-29 organic compounds from meat charbroiling, Environ. Sci. Technol., 33, 1566-1577, 1999b.

Schauer, J. J., Kleeman, M. J., Cass, G. R., and Simoneit, B. R. T.: Measurement of emissions from air pollution sources. 3. C-1-C29 organic compounds from fireplace combustion of wood, Environ. Sci. Technol., 35, 1716-1728, 2001.

Schauer, J. J., Kleeman, M. J., Cass, G. R., and Simoneit, B. R. T.: Measurement of emissions from air pollution sources. 5. C-1-C32 organic compounds from gasoline-powered motor vehicles, Environ. Sci. Technol., 36, 1169-1180, 2002a.

Schauer, J. J., Kleeman, M. J., Cass, G. R., and Simoneit, B. R. T.: Measurement of emissions from air pollution sources. 4. C-1-C27 organic compounds from cooking with seed oils, Environ. Sci. Technol., 36, 567-575, 2002b.

Seinfeld, J. H. and Pankow, J. F.: Organic atmospheric particulate material, Annu. Rev. Phys. Chem., 54, 121-140, 2003.

Volkamer, R., Jimenez, J. L., San Martini, F., Dzepina, K., Zhang, Q., Salcedo, D., Molina, L. T., Worsnop, D. R., and Molina, M. J.: Secondary organic aerosol formation from anthropogenic air pollution: Rapid and higher than expected, Geophys. Res. Lett., 33, doi:10.1029/2006GL026899, 2006.

Wang, L., Atkinson, R., and Arey, J.: Dicarbonyl products of the $\mathrm{OH}$ radical-initiated reactions of naphthalene and the $\mathrm{C}-1-$ and C-2-alkylnaphthalenes, Environ. Sci. Technol., 41, 2803-2810, 2007.

Weitkamp, E. A., Sage, A. M., Pierce, J. R., Donahue, N. M., and Robinson, A. L.: Organic aerosol formation from photochemical oxidation of diesel exhaust in a smog chamber, Environ. Sci. Technol., 41, 6969-6975, 2007.

Zhang, Q., Jimenez, J. L., Canagaratna, M. R., Allan, J. D., Coe, H., Ulbrich, I., Alfarra, M. R., Takami, A., Middlebrook, A. M., Sun, Y. L., Dzepina, K., Dunlea, E., Docherty, K., DeCarlo, P. F., Salcedo, D., Onasch, T., Jayne, J. T., Miyoshi, T., Shimono, A., Hatakeyama, S., Takegawa, N., Kondo, Y., Schneider, J., Drewnick, F., Borrmann, S., Weimer, S., Demerjian, K., Williams, P., Bower, K., Bahreini, R., Cottrell, L., Griffin, R. J., Rautiainen, J., Sun, J. Y., Zhang, Y. M., and Worsnop, D. R.: Ubiquity and dominance of oxygenated species in organic aerosols in anthropogenically-influenced Northern Hemisphere midlatitudes, Geophys. Res. Lett., 34, doi:10.1029/ 2007GL029979, 2007. 